\title{
6 \\ Medicine, money and mutual aid
}

\section{Dirk Luyten and David Guilardian}

In 2015, average out-of-pocket patient payments would amount to some 18 per cent of healthcare expenditures, almost 80 per cent being paid for by the national compulsory health insurance scheme, while revenues from voluntary insurances fund less than 5 per cent of the total amount. ${ }^{1}$ Two hundred years ago, a patient would have to pay the total bill by themselves or turn to local public welfare. In the last two centuries, the financing of healthcare obviously went through major changes. This chapter will highlight the shift of both healthcare and hospital financing, from local welfare to state intervention through the creation of private schemes and institutions, especially mutual aid societies.

Economic and financial issues in medical history have not received as much attention in Belgium as compared to the Netherlands, Great Britain or France. ${ }^{2}$ And most of the time they have been touched upon indirectly. In the 1990s sociopolitical literature on the history of social security, for instance, the financial aspects of medicine in Belgium have been analysed at macro level, but always in the context of a larger political and social history. Publications on the history of the mutual aid sector are another place to look for indirect examinations of the Belgian healthcare economy. The history of public healthcare institutions constitutes a third field of research that has allowed historians to peek at the financial realities of medicine in the past.

The economy of the private healthcare sector and the study of social groups financing medical care through their own means remain a blind spot in current research. And although the development of private health insurance companies has been less significant in Belgium than in a neighbouring country such as the Netherlands, the specificities of the Belgian private health insurance sector are 
still to be studied in detail. ${ }^{3}$ Drawing from the existing historiography, this chapter will thus mainly explore the public or semipublic spheres of healthcare. ${ }^{4}$

\section{Healthcare and hospitals before 1795}

If we divide the population roughly between the wealthy, the poor and the middle class, there are three different possibilities as to healthcare consumption. To the higher classes, private home care was the norm. The wealthiest paid in full the remedies of their pharmacist, the visits of their physician or the rare operations that the surgeon would perform in their living room. For the poor, public and private welfare would intervene, especially in cities where the local authorities paid for a doctor and surgeon whose task was to care for the poor, and where a hospital would offer them nursing care. ${ }^{5}$ As for the craftsmen and workers who were neither rich nor poor, membership to a craft guild or a brotherhood often offered the benefit of some form of mutual assistance. The most thriving among these organisations set up 'sick funds' or even built their own almshouses to spare their members the humiliation of having to resort to charity in time of sickness. ${ }^{6}$ An alternative would be to turn to home care congregations such as the Black Sisters or Alexians. ${ }^{7}$

Institutional healthcare, provided by hospitals, was limited to nursing care provided essentially by religious congregations, with very little physician involvement. Financially, they relied almost entirely on the income of their estate and gifts from wealthy patrons. ${ }^{8}$ All who could afford it avoided these establishments for they bore the mark of poverty and death. Local public authorities in main cities only intervened when they feared for public health and security; they, for instance, funded the construction of 'pesthuyskens' (plague houses) or institutions for the mentally ill. ${ }^{9}$ What percentage of the population would turn to a doctor in the Ancien Régime? Considering most people in the countryside would resort mainly to religious or superstitious relief (e.g. quacks), a doctor would only be called for by the bedside when death already approached. In cities, doctors were more frequently 
consulted. In Brussels, extrapolations on the basis of a series of practitioner records around 1780 would indicate that some 16 per cent of the population would ask for a doctor. ${ }^{10}$

\section{The French reorganisation and the dual society} (1794-1850)

The French Régime would fundamentally change the financing of healthcare by introducing two new ideas. The first idea contended that the well-being of citizens could no longer be left to the goodwill of philanthropists and charitable organisations but needed to be a major concern to the nation as a whole. The French Revolutionary Constitution of 1793 asserted: 'Public relief is a sacred debt. Society owes subsistence to its less fortunate citizens.' ${ }^{11}$ Although the French Assemblée quickly realised that free universal healthcare was financially unviable, it ordered the nationalisation of all private care institutions, foundations and almshouses (décret du 23 messidor II). ${ }^{12}$ Institutional healthcare would be automatically public, and directed by a newly created local board called civil hospitals (hospices civils). At the same time, poor relief and healthcare were entrusted to the new local welfare bureaus (bureaux de bienfaisance), who appointed the 'poor doctors' (Figure 6.1). Placed under the control of local authorities, welfare did not rest directly on the purse of the central state; only the care of certain categories of destitute people (blind people, profoundly deaf people, or prostitutes arrested by the police, for instance) remained statefinanced. ${ }^{13}$ The reform did cause welfare institutions to lose parts of their traditional incomes (tithes, feudal rights, annuities from guilds, etc.). ${ }^{14}$ In Leuven, the annual income of the city hospital and hospices dropped by 38 per cent (from almost 120,000 F before the French annexation to less than 75,000 F in 1800), a deficit that municipalities would have to compensate. ${ }^{15}$

The second idea had to do with the new role of the revolutionary state: it was believed that the state should be the main recourse of its citizens in time of need and that private intermediary organisations should be done away with. Craft guilds, brotherhoods and their mutual aid systems were abolished. Those who could not afford the 


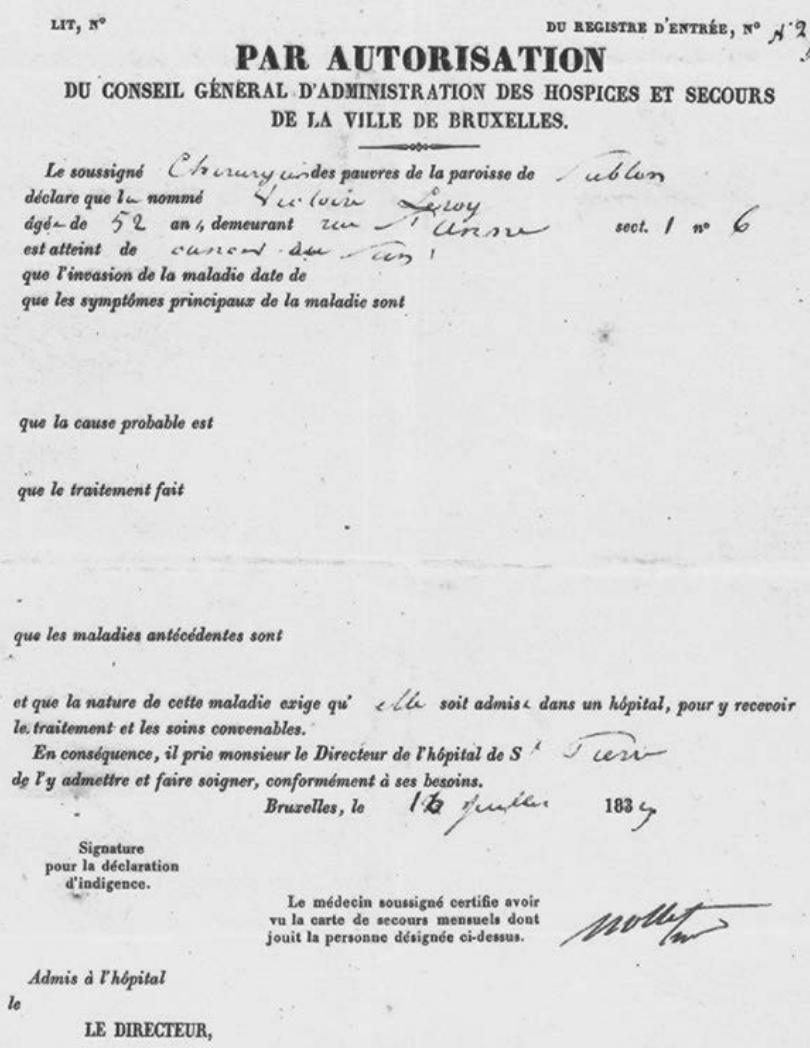

Figure 6.1 Poor doctor's certificate, issued for the director of St-Pierre Hospital in Brussels, indispensable for admission, 1837.

cost of private care would now have to turn automatically to public welfare, which acquired some kind of monopoly. The 'French system' would be maintained but challenged, especially after 1850, both by the return of Catholic charities, and by the need for new mutual aid societies. 


\section{Private charity returns (1850-1900)}

The medical marketplace in mid-nineteenth-century Belgium was an unregulated space in which qualified doctors competing for 'clients' were free to determine their fees and (paying) patients free to choose among a growing range of healthcare providers. Although expensive physician fees (in 1850 a visit to a doctor cost the daily wage of a worker), cultural resistance to medical consumption and availability of free public medical services kept the largest part of the population on the fringes of the market, ${ }^{16}$ options for medical care slowly expanded for the poorer class too.

In the second half of the century, the weight of individual philanthropy, such as that of local elites or of upper-class Catholic women's societies, decreased to give way to large-scale organised forms of philanthropy. As public welfare institutions grew in size and number, Catholic private charity developed too. ${ }^{17}$ From 1841 on, the Catholic Society of St Vincent de Paul, for instance, established local 'conferences' in many parishes all over the country and built outpatient hospitals in small villages (see Chapter 2, pp. 70-1). ${ }^{18}$ This shift to organised charity brought about rationalisation, gains in efficiency and an enhanced control over the poor it served. ${ }^{19}$

In theory, all hospitals were and had to remain public welfare institutions dependent on local governments. The continued presence of Catholic nursing personnel within their walls, however, often led to growing tensions between religious staff and lay boards of directors. This is one of the reasons - coupled with the fast expansion of religious orders in the nineteenth century - why the Catholics kept pushing for the establishment and financing of their own private institutions. New private hospital foundations with independent boards had, in fact, been authorised under French ruling (Arrêtés from the years X, XII and 1806), provided that they were placed under the supervision of public welfare. ${ }^{20}$ Unlike the situation in France, religious charity in Belgium was allowed to keep a crucial place in the national landscape of healthcare. It would also take part in the mutual aid system. 


\section{Workers' health insurance: social control and a first step towards collective responsibility, 1850-94}

In the first half of the nineteenth century, most workers lived at a subsistence level. After 1850, a modest rise in salary rates allowed the better paid among them to start saving modestly. Most then elected to invest in small-scale initiatives of the labour movement such as mutual societies or cooperatives. ${ }^{21}$ Mutual societies grew out of the principles of reciprocity and resource pooling. They allowed workers with too low an income to mutualise limited savings to no longer rely on public assistance in time of sickness. ${ }^{22}$ Outside of the paternalistic, charitable, partisan sphere of liberal and Catholic organisations, some mutual societies had been set up by workers themselves with a different set of rules and aspirations. Workers belonging to one specific occupational group, especially craftsmen, would pool a fraction of their income together to cover the risk of sickness of their peers, thus somehow picking up the thread that had been cut by the French reorganisation. ${ }^{23}$

In the mid nineteenth century, most mutual aid societies only paid their members a daily sickness allowance when illness, old age or an accident prevented them from working. They also partially compensated the cost of the funerals of deceased members. Considering the limited efficacy of orthodox therapeutics at the time, the rarity of practitioners in the countryside and the high cost of medical treatment, monetising was, in working-class culture, often more oriented towards the dead than the living. Proper funerals, with the social and religious obligations they entailed, ${ }^{24}$ were prioritised over the receiving of standard medical care. ${ }^{25}$

Despite mutual aid alleviating some of the pressure put on Welfare funds, the 1851 law on mutual societies ratified by a wary Liberal government in the wake of the social protest of 1848, hints at the authorities' distrust and prudent ways of dealing with these new types of organisations. For the latter, legal recognition and fiscal advantages came at the price of direct control by the municipality and sanctions in case of non-compliance with the law. ${ }^{26}$ While philanthropic (liberal or Catholic) mutual funds, or societies set up by employers and factory owners, were tolerated, the authorities did not hesitate to enforce the 1791 coalition ban against organisations 
of factory workers, arguing that they sometimes functioned as secret trade unions. The mid-nineteenth-century textile sector in Ghent counted 12 factory-based mutual societies, with a total membership of 2,200. ${ }^{27}$ In 1886, mutual aid funds in Belgium served 65,000 affiliated members (of a national population of about 6 million in 1890); this was less than in 1850 (70,000 members for a total population of 4.3 million in 1846). For the government, the moralisation of workers needed to be the primary goal of these organisations; prizes were awarded to those, particularly of bourgeois origination, most successful in educating the poorer classes. ${ }^{28}$

Moralisation was central to the mission of Catholic mutual societies created in the 1850 s and 1860 s too, just as was the preservation of the Catholic faith in the face of the secularisation policies adopted by a succession of Liberal governments. Organised at parish level and often embedded in charity structures, Catholic mutual societies were managed and partly funded by members of the elite, or so-called honorary members who contributed high membership fees without being entitled to any benefits. Both liberal and Catholic developments in the field of mutual aid sought to prevent the emergence of socialism and workers' organisations. ${ }^{29}$

But the social unrest of the late nineteenth century forced new issues into the conversation. Spurred by a severe economic recession in the industrial regions of Wallonia, the violent strikes of 1886 brought the appalling working and living conditions of Belgian workers to national attention. As a political response to the strike, the Parliamentary Inquiry Commission tasked with investigating this state of affairs advocated in favour of mutual aid funds as tools of social pacification. Even further, it encouraged class cooperation and worker involvement in the management of these organisations.

The issue of mutual aid came at the forefront of public attention again in 1895 during the debates on the reform of public assistance. Socialists from the newly founded Labour Party (the Parti Ouvrier Belge, or Belgische Werkliedenpartij) favoured a system of compulsory social insurances as an alternative to public assistance. They were of the opinion that obligation should stem from solidarity: such a system would entail the redistribution of the national income and contribute to the advancement of society as a whole 
rather than providing insurance solutions for isolated individuals. $^{30}$ The Catholics had already raised the idea of a compulsory health insurance during their annual Catholic Congresses in the late 1880 s, but only for low-paid industrial workers and financed by the industry itself. ${ }^{31}$ At that time, concern of the governing class for the moralisation of working-class citizens and for their learning of simple principles of financial caution trumped technical issues of funding and sparse medical considerations. In addition, a curtailing of the free market still seemed an undesirable prospect for most. ${ }^{32}$ For the first time, however, the idea of a nationwide system of shared responsibility for healthcare costs had been put forth.

\section{Subsidised liberty (1894-1944)}

All in all, the last quarter of the nineteenth century was a period of growth in healthcare thinking and strategising. Economic crises and social unrest demanded that the state face up to the situation of the working class and spurred a national public reflection on the issue of healthcare for all. As a growing number of people and political organisations looked to forms of organised solidarity to remedy the costly plague of ill health, the state sought to unburden the load of public assistance by acting as a distant unifying force in a sector still mostly livened up by Catholic initiatives. At the same time, the growing influence of the socialist movement forced most political families to adopt one or other aspect of the socialist agenda, lest they lose a portion of their constituency. This set off a century-long search for more democratic and universal solutions to the problem of healthcare financing.

In public debates about the health of the Belgian population, the focus moved away from moral concerns towards the cost of care in and of itself: the possible ways to calculate it, to contain it, to share or allocate it. New techno-financial tools and arguments were introduced into healthcare planning and mutual aid thinking. All the while, the idea of a national system of compulsory insurance kept resurfacing time and again, but political and ideological discords prevented it from materialising into more than words.

With the new 1894 law on mutual aid societies, direct control and threats of sanction gave way to a new regime of 'subsidised 
liberty'. The central state preferred to restrict its role to the subsidising from afar of independent organisations. From 1898 on, mutual societies with an official accreditation could qualify to receive state subventions. Municipal control abated. This new system, in combination with the rise of workers' living standards and renewed efforts - particularly from the Catholics - to set up more organisations, led to an increase in mutual aid membership. In 1890, Belgian state-accredited mutual funds counted 54,347 members. In 1900, this figure reached 185,201.33

In the two last decades of the nineteenth century, habits of medical consumption changed due to the democratisation of the medical market, ${ }^{34}$ the development of antiseptic surgery and the increase of purchasing power. Mutual aid offers transformed as workers became more willing to invest part of their income in medical services that they could not afford or were not interested in before. In the late 1880s in the province of Namur, mutual societies started to trade the system of daily sickness allowance for a system of reimbursement of medical expenses. ${ }^{35}$ A series of factors - state subsidies, centralising and rationalising incentives, industrial accident risk coverage transferred to private insurance companies (1903) and disability insurance passed on to the more generously state-funded federations of mutual organisations - enabled local mutual aid funds throughout the country to propose an expanding range of options, starting with a basic 'medical-pharmaceutical' coverage (reimbursement of doctor fees and pharmacist bills). Some promoted preventive healthcare or offered additional coverage for specialised treatments like surgical operations. ${ }^{36}$

Inevitably, the growing involvement of mutual societies in medical care led to conflicts with a fast-organising medical profession still bent on defending a patient's free choice of practitioner and a physician's right to freely set his fees. To contain the cost of medical care, mutual societies offered physicians contracts with fixed fees to take up the care of all their members. ${ }^{37}$ Medical practitioners resented this type of agreement. Some accepted, however, to ask less for the treatment of workers but not for that of the craftsmen who made up a large part of mutual aid membership. In their dealings with pharmacists, mutual societies used as leverage the threat of opening their own 'people's pharmacies' ${ }^{38}$ In 1912 in Antwerp, disgruntled physicians organised a strike against the (liberal) society 
Help Uzelve (Help yourself). The latter offered free basic, and later specialised, medical care to a growing membership, steadily eroding the independent practitioners' share of the medical market. ${ }^{39}$

But the better organised the medical profession became, the greater weight it was able to hold in its negotiations with mutual aid funds. The firmer demands of physicians constituted a new unpredictable variable in the system of healthcare financing. By comparison, the costs of daily sickness allowance paid to a society's members were easy to control: the fee lowered the longer the sickness lasted, always had a time limit (often six months) and decreased on a sliding scale the older a member got. Often membership was denied to applicants over forty-five or fifty years old. ${ }^{40}$ But since payment for medical care had a more open-ended character, mutual aid organisations had to establish new strategies of cost limitation. To solidify their position, Brussels mutual societies organised in 1863 into a federation; the pooling of local mutual aid resources and cooperation between contracted physicians helped pushing the development of healthcare provision further. ${ }^{41}$ In Ghent, the local mutual aid society took on the payment of sickness allowances, while the coverage for medical care was organised at the federation level and funded by a separate contribution from members. ${ }^{42}$ The most radical solution to skyrocketing and unpredictable costs consisted simply in no longer offering members the 'medical-pharmaceutical' coverage and to increase the amount of the daily sickness allowance instead, which could then be used to pay a doctor. An alternative was to put an upper limit - per year and per member - to the coverage of medical expenses, which would then allow mutual funds to extrapolate their maximal budgets for each year. ${ }^{43}$ In the countryside, physicians and mutual aid societies often opted for an alternate subscription system: the organisation paid a fixed fee per member to a number of local physicians between whom healthcare-seeking members were free to choose. This was an interesting solution that provided practitioners with a stable income in areas with low medical demand. ${ }^{44}$

The development of mutual funds must also be studied in the political context of what is termed today the 'pillarisation' of Belgian society; a process of fragmentation and reorganisation of the country's social life around the three main dominant political families competing for national dominance. Most organisations 
and institutions belonged to one of the three political 'pillars' whether socialist, Catholic or liberal - and each of these pillars controlled a large part of the social and cultural infrastructures of the country. Because it privileged organisations over the state, pillarisation impeded direct state intervention and state institutionbuilding. Unsurprisingly, it agreed with the idea of subsidiarity, the cornerstone of Catholic social ideology and of the social policy of the Catholic governments in office between 1884 and 1914. The expansion of mutual aid societies was one of the numerous expressions of this pillarisation process, a process that would deeply inform the shape of care provision and preventive medicine in the twentieth century. While Catholic congregations and organisations used this situation to expand their institutional and medical reach, ${ }^{45}$ socialist mutual societies started building small surgical facilities - they were not able yet to support the building of a comprehensive infrastructure - to offer healthcare to workers potentially interested or already invested in socialism and challenge the Catholic dominance in this field. ${ }^{46}$

Although the system of subsidised liberty improved health coverage at the turn of the twentieth century, it left three population groups vulnerable. First, in rural regions, mutual societies predominantly organised the wage earners and had difficulties attracting the self-employed, particularly farmers. Similarly, rural elites, unlike their urban counterparts, were little inclined to support the development of mutual aid. Local authorities, too, felt no urgency to bolster mutual funds because they did not have to cope like cities had with fluctuating poverty resulting from the business cycle. The usually lenient positions adopted by public assistance institutions towards the needy in sparsely populated rural communities further tempered the perceived need for such solidarity mechanisms. ${ }^{47}$ In the rural province of Namur, the farmers' lack of interest in mutual aid was attributable to the influence of local priests who favoured traditional charity too, and did nothing to stimulate the foundation of Catholic mutual funds. ${ }^{48}$

The second underrepresented group among mutual aid members were women and children. As a general rule, mutual societies only covered (male) breadwinners. Insuring every member of a family was far too expensive and women were considered to be at higher risks than men. In 1900, women made up only 5.5 per cent of 
the total number of members in mutual societies. ${ }^{49}$ The creation of women and children's, or so-called familial, mutual societies provided a first solution to this problem. ${ }^{50}$

Low-paid workers constituted the third group, among which mutual society membership was rare, a group whose situation the proponents of a compulsory system of health insurance particularly wanted to see improve. ${ }^{51}$

The political debate about the possibility of implementing such a compulsory system provided various occasions to discuss the financial coverage mechanisms of medical care for the lower social classes. The 1912 project of the Catholic government, inspired by the British system (Lloyd George), defended the continuation of subsidised liberty. In that system, workers who could not pay or were refused membership to a mutual aid fund were to be insured, with lower benefits, via state mutual funds organised at regional level. Those outside the labour market would remain dependent on public assistance. ${ }^{52}$ Liberals and socialists criticised the Catholic scheme by using new arguments based on financial methods such as risk assessment: these 'regional councils', they asserted, could not be financially viable since their members combined a highrisk profile with limited financial means to pay their contribution. According to them, this type of risk should be covered by repartition, and thus solidarity.

The 1913 project of socialist politician Camille Huysmans hints at a growing consciousness of the cost of care as well; it contended that a compulsory sickness insurance scheme could be financed simultaneously by employers, their employees and the state. But employers, resisting the idea of state intervention and of their own responsibility towards their workers, opposed actuarial risk principles to that socialist notion of solidarity: young wage earners should not contribute the same amount as their older counterparts, since they were less likely to get sick; the risk of illness was purely personal and premiums should be calculated on an individual basis, using mortality and sickness tables. Additionally, the cost of ill health should be borne by the workers alone. ${ }^{53}$

The First World War brought a new awareness of the vulnerability of the population and of the need to preserve the productive forces of the country. Belgium had always relied on international imports for a significant portion of its food needs. Suddenly plunged 
into deep economic disarray and weakened by trade embargoes, the country under German rule faced massive unemployment rates, a general impoverishment of the population and a risk of famine on an unprecedented scale. Many people could no longer afford medicine or the visit of a physician. In September 1914, to prevent the worst, several members of the Belgian economic elites founded, with the support of the exiled Belgian government, the National Relief and Food Committee, a 'parallel social state' that gathered and distributed national and international aid within the country. The committee coordinated social policies in cooperation with organised labour. In addition to food, it provided free medical care to the unemployed and redistributed funds to mutual aid societies, but this time on the condition that they offered coverage not only to individual male breadwinners, but also to every member of their family, for the lives of women and children needed protection too. The committee organised care for babies and children, and supplied meals to expectant mothers. Preventive care (against tuberculosis among others), too, became central to the committee's efforts and continued well after the war. ${ }^{54}$

After 1918, despite the achievements of the innovative National Relief and Food Committee, the Belgian government resumed its policy of subsidised liberty. Catholic opposition to state intervention in an area that had historically been the prerogative of religious organisations was partly responsible for the status quo. Catholic pushbacks also ensured that the creation of a standalone Ministry of Health would not come to be until after the Second World War. ${ }^{55}$ State financial support to mutual aid organisations increased after 1918, however, and became a permanent feature of interwar governmental policies. The National Committee's efforts towards the coverage of the working-class and families were carried on by the various coalition governments that followed the end of the war (and often included the Socialist Party). The largest part of this support went to the financing of medical-pharmaceutical services. ${ }^{56}$ Specialised structures for women within mutual aid organisations took over the role of independent women's mutual societies. ${ }^{57}$ Large sums were invested in tuberculosis prevention. Other categories of preventive care had to do with pregnant women, babies and children: open-air holiday camps, for instance, were offered as part of tuberculosis preventive efforts. Since the receipt of subsidies 
was subject to compliance to certain conditions, the system of state subsidies led to more uniform practices in healthcare provision. ${ }^{58}$ The financing of mutual aid and the development of healthcare infrastructures also resumed at province and local level, primarily through subsidies or cooperation with private actors. ${ }^{59}$

More and more people gained access to health coverage, which became relatively less expensive. In 1934 a visit to a general practitioner costed $8 \mathrm{BF}$, while an unskilled worker in the building industry in Brussels earned 4,10 BF per hour. ${ }^{60}$ In 1926, 75 per cent of the rural Kempen population already enjoyed membership to a local mutual aid fund. ${ }^{61}$ In the 1920 s, generous state subsidies initiated by the socialist minister of labour Joseph Wauters, as well as a slow reorganisation and centralisation of mutual aid, allowed for the pooling of resources at regional level. ${ }^{62}$ This process contributed to the general expansion of the medical offer, ${ }^{63}$ including to the construction of brick-and-mortar facilities, to the multiplication of prevention initiatives and of specialised services.

The introduction of universal male suffrage in 1919 and the country's post-war swing to the left positively impacted the development of the socialist flank of the mutual aid sector. To keep abreast of the growing specialisation of medical care, socialist mutual organisations built their own polyclinics, offering specialised care and the benefit of up-to-date technological equipment to the working class at a fixed affordable fee ${ }^{64}$ Socialists also built clinics, such as the People's Clinic in Ghent, one of the strongholds of socialist organised labour. In that specific clinic, cost control was achieved by applying the principles of division of labour: each patient was examined by a general practitioner before being sent to a specialist and each patient had a personal file. Maintaining a healthy financial balance, however, proved to be difficult; the price of medical care had to be raised and patients were expected to pay an entrance fee in addition to the cost of their treatment. ${ }^{65}$ In the 1920s, as a countermove to the flourishing of socialist structures, industrial employers created at company level a parallel network of mutual aid organisations that similarly contributed to the general expansion of health coverage: in 1931, however, about a million workers still remained uninsured. ${ }^{66}$

As for the Catholic labour movement, it first lagged behind but soon caught up, broadening and diversifying its medical 
infrastructure, building clinics and sanatoria like their political rivals. In this context of growth, cost control and the regulation of the health market became crucial. Individual mutual aid organisations each implemented their own system of cost containment, usually involving the hiring of physicians with fixed-fee contracts. In 1920, attempts to conclude a national agreement between the medical profession and the mutual aid sector pushing for the standardisation and capping of medical fees, failed. Conventions at regional and provincial levels, however, were successfully negotiated. ${ }^{67}$ While socialists like the leader of the national federation of socialist mutual funds, Arthur Jauniaux, argued again for the existence of one single mutual society with a unified fee policy, Catholics advocating organisational pluralism still stood in the way of a compulsory health insurance scheme. ${ }^{68}$ Nevertheless, healthcare financing and the mutual aid sector, now enjoying the full and permanent support of the state, were moving towards centralisation and standardisation. ${ }^{69}$

\section{Hospitals no longer only for the poor (1890-1944)}

By the end of the nineteenth century, the private healthcare institutions would not only be organised by a Catholic congregation or a mutual aid society, but sometimes founded by surgeons or specialist physicians, for a middle- and upper-class population eager to benefit from new technologies originally developed in hospitals. Operating outside of what had been thus far the charitable logic of institutional medicine, these establishments initiated a new financing model resting entirely on patient-paid revenues. Although the admission of occasional wealthier paying patients had been customary in Belgian public hospitals in the nineteenth century, it had always been with the understanding that the better-off did not really belong there.

In contrast to the development of private medical services and mutual aid clinics, municipalities experienced great difficulties in sustaining and growing their network of public hospitals. The cost of hospital construction - especially of new specialised facilities and of everyday hospital management was as prohibitive as ever. In the Brussels area, a few hospitals built after 1883 (Laeken, Forest, 
Molenbeek) closed after the First World War. Few municipalities banded together to create inter-municipal institutions; most kept sending their poorer residents to the better-equipped city hospitals. ${ }^{70}$ The search for private - sometimes foreign - funds was one of the ways municipalities got around their lack of capital. To rebuild the city's historic St-Pierre Hospital according to the new scientific and technological standards of the time, for instance, the Brussels Public Welfare and the Brussels University successfully sought the support of the American philanthropic Rockefeller Foundation directly after the First World War. ${ }^{71}$

The provision of affordable healthcare through mutual aid clinics and polyclinics negatively impacted the rate of public hospital use since mutualists no longer depended on public assistance physicians and institutions. One of the solutions available to municipal hospitals experiencing a decline in their user population was to open their doors to paying patients. While not doing so explicitly, the 1925 Law on the Reform of Public Assistance (which merged each municipality's welfare bureaus and hospitals into one single Commission d'Assistance Publique (CAP)/Commissie van Openbare Onderstand) and the ensuing debates admitted the necessity of attracting and accommodating a wider array of patients, mutual aid members and insured individuals included. ${ }^{72}$ Hospitals could become an affordable option for lower-middle-class and middleclass patients seeking specialised and technological treatments; in return, patient-paid revenues would constitute a significant input to the finances of public institutional medicine. Now CAPs were free to open clinics for paying customers with comfortable private rooms. ${ }^{73}$

Paying public hospital users were charged the basic legal daily rate, plus a series of additional charges for blood transfusion, medicine, nursing material, radiography, laboratory analysis, radiumtherapy, transportation, etc. They also paid their physician's or surgeon's fees separately, especially if the latter did not belong to the hospital staff. ${ }^{74}$ Between 1926 and 1934, the proportion of paying patients treated in the two main CAP hospitals of Antwerp (St-Elisabeth and Stuivenberg) would range yearly from 8 per cent to almost 25 per cent. In 1934, private CAP clinics opened in both hospitals. ${ }^{75}$ In Brussels, CAP welcomed a proportion of paying patients of nearly 16 per cent and 12 per cent in its two 


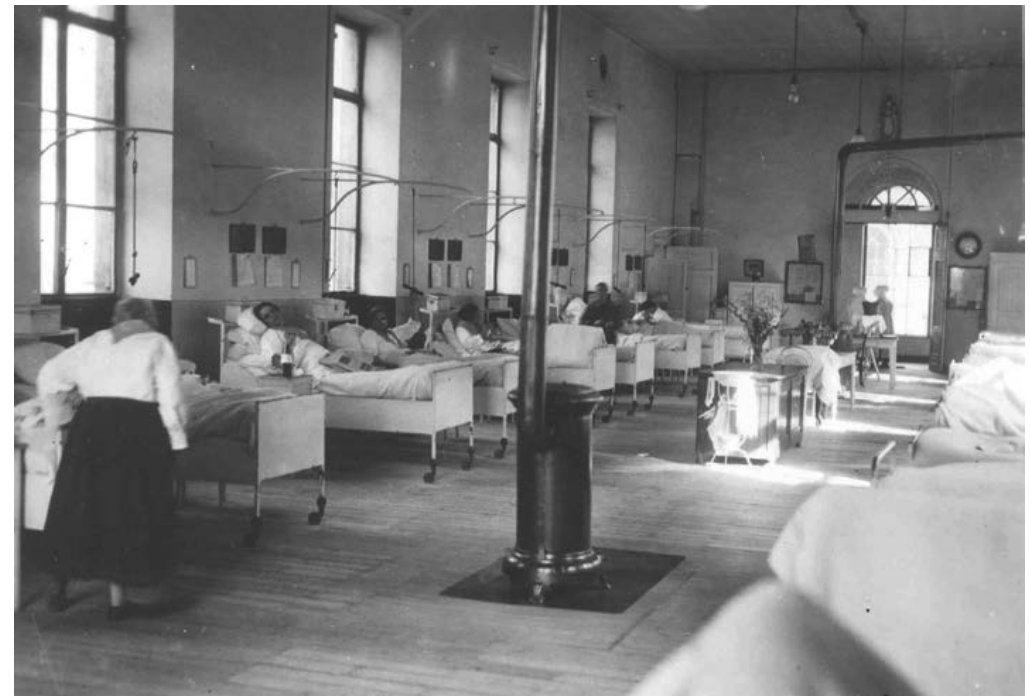

Figure 6.2 Two possibilities in the 1930s: either the common sick ward, free (as in this picture), or the single room with private bathroom, for paying patients. Ward 14, St-Jean Hospital in Brussels, around 1935 .

major hospitals during the year $1926 .{ }^{76}$ However, the income from paying admissions only amounted to 8 per cent and 5 per cent of the hospitals' global expenses (Figure 6.2 and Table 6.1). ${ }^{77}$

In 1935, a wing of the freshly rebuilt St-Pierre Hospital, named Clinique Héger, was exclusively dedicated to paying patients while the main building itself remained allocated to the poor. Four years later, the new specialised Cancer Institute Jules Bordet combined four floors for the poor with three floors for paying patients (who occupied one-third of the beds). ${ }^{78}$ Despite these changes the public healthcare system kept losing money. By 1933, the CAP hospitals of the capital suffered a deficit of 9.5 million F. ${ }^{79}$

Notwithstanding the hardships of public healthcare financing, the development of medical institutions carried on, galvanised by the mushrooming of mutual aid clinics and private health institutions, the general public's interest in safe surgery, technological innovations and the antibiotic revolution of the 1930s. The 
Table 6.1 Paying patients in the two main Brussels hospitals (1926)

\begin{tabular}{|c|c|c|c|c|c|c|c|}
\hline Hospital & $\begin{array}{l}\text { Number } \\
\text { of beds }\end{array}$ & $\begin{array}{l}\text { Total number of } \\
\text { patients admitted } \\
\text { during the year }\end{array}$ & $\begin{array}{l}\text { Number of paying } \\
\text { patients admitted } \\
\text { during the year }\end{array}$ & $\%$ & $\begin{array}{l}\text { Income } \\
\text { from paying } \\
\text { patients }\end{array}$ & $\begin{array}{l}\text { Total hospital } \\
\text { expenditure }\end{array}$ & $\%$ \\
\hline Brugmann & 760 & 5,657 & 891 & 15.8 & $546,671 \mathrm{~F}$ & $6,735,902 \mathrm{~F}$ & 8.1 \\
\hline St-Jean & 570 & 5,410 & 642 & 11.9 & $256,255 \mathrm{~F}$ & $5,166,126 \mathrm{~F}$ & 5.0 \\
\hline
\end{tabular}

Source: Rapport Annuel de 1926 (Brussels: Assistance Publique, [1927]), 24-5. 
number of hospital beds (psychiatry included) grew from 40,000 in 1933 to nearly 52,000 in 1940, showing a growth rate of about 1,700 beds a year. ${ }^{80}$

\section{Regulation and control: the Belgian welfare state since 1944}

During the Second World War, German occupiers considered implementing a compulsory health insurance in Belgium resembling that of the German healthcare system. This vision was frustrated by Catholic civil servants from the Ministry of Labour and Social Affairs who feared that marginalising the role of mutual organisations would undermine Catholic efforts in healthcare and weaken Catholic presence in the life of the Belgian people. ${ }^{81}$ It is, instead, a clandestine pact of social solidarity concluded just before the end of the war between some Belgian union and employer representatives assembled under the name Comité patronal-ouvrier that brought about change. A blueprint for a national social security policy, the pact served as a draft for the Social Security Act for salaried workers of December 1944. The decree law that followed instructed that all Belgian employees, regardless of their wage level, be protected by a compulsory health insurance that would be funded by the state, employer contributions and deductions from employees' salaries. For the first time in the history of the country, all employers had no choice but to support the general provision of medical care for the men and women they employed. ${ }^{82}$ Despite the fears of the Catholics, mutual societies were to remain central to the functioning of the system: insurance payments would be channelled through them. For the self-employed, an obligation to contract a basic insurance - to cover 'major' medical 'risks' at least - followed in 1964. A year later, the same requirement applied to civil servants, and in 1969 , to the whole population. ${ }^{83}$

The new compulsory insurance scheme of 1944 transformed the role of the state. The financing of healthcare became part of public service and authority in the matter was progressively delegated to a new administrative body: the National Institute for Health and Disability Insurance, or INAMI/RIZIV. But if the system was based on the principle of national solidarity between wage earners, 
risks were unevenly spread among mutual organisations since they catered to social groups with different risk profiles. Because bluecollar workers made up most of their membership, socialist mutual aid funds, for instance, had to deal with higher risks than their Catholic counterparts while also taking in far less income since member contributions were wage based. This resulted in early financial problems for the new system: in 1948, it registered a deficit for the first time, which rapidly acquired a permanent character. Rising expenses were caused by demographic expansion, the development of medical sciences and expensive technologies, as well as by the inclusion into insurance services of social groups entitled to health benefits despite not being able to pay their share. Deficits varied across the mutual aid market: in 1949, for instance, most mutual societies were losing money, except for the Catholic organisations united within a federation of Christian mutual funds (De Landsbond der Christelijke Mutualiteiten/La Mutuelle Chrétienne). ${ }^{84}$

Belgian historian Guy Vanthemsche has offered a sophisticated analysis of the compromise reached in 1949 to bridge the Catholics' and socialists' opposing views on solidarity. For socialists, who still wished for the creation of a single mutual society, national solidarity should prevail over all other concerns (i.e. the state should close the gap between incomes and expenses by granting more subsidies to mutual organisations in deficit). To the Catholics, solidarity should be organised only among the members of each individual mutual society. The 1949 compromise specified, on the one hand, that contributions to health insurance funds should be distributed among all mutual societies, taking into account the risk profile of each society's membership (organisations with members more in need of care received a bigger part of these contributions); on the other hand, mutual societies had a financial responsibility and - this was a demand coming from the Catholic side of the sector - in case of deficit, should ask an extra contribution from their members or lower the benefits that they offered. In the 1950s, a period of great political polarisation, the unstable compromise was called into question; it is only in 1963 with the implementation of the Leburton law on sickness and invalidity insurance that a long-lasting reform could be achieved (Figure 6.3). The latter pushed the separation of benefits compensating the loss of wage and reimbursements of healthcare expenses, and it secured higher financial support from 


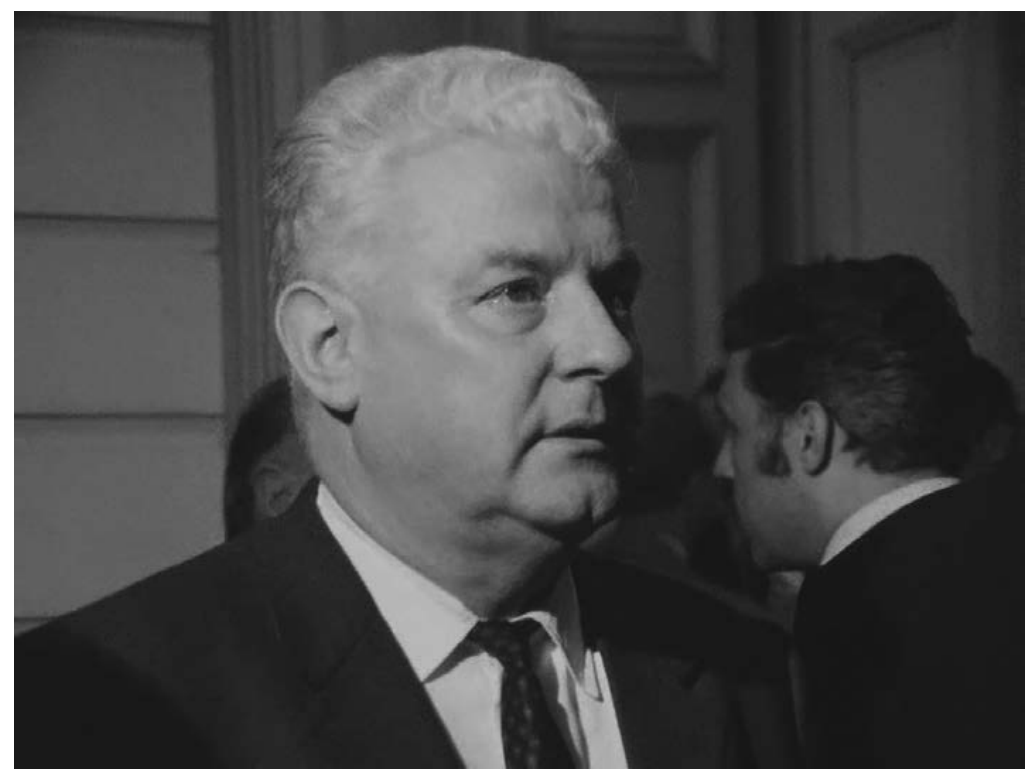

Figure 6.3 Edmond Leburton (1915-97), the minister who gave his name to a law on financing of the sickness insurance in 1963. Screencap from video 'Conseil des Ministres sur la grève des mineurs du Limbourg', 1970.

the state. All the while, the mutual aid sector agreed to assume a greater level of financial responsibility.

The transformation of healthcare after 1944 impacted the medical profession too. To maintain the financial viability of the system, medical fees, for general practitioners as well as for specialists, had to be regulated, with a central role for the state. This restricted the freedom of doctors to determine their fee: as a consequence of the compulsory character of sickness insurance for wage earners, regulated fees covered more patients: a medical journal estimated the expansion of people covered by a sickness insurance after the introduction of social security from 3.5 to 5 or 6 million. ${ }^{85}$ Regulation attempts met with resistance as conflicts between the state, the medical profession and mutual funds - acting, in the name of their members, as a pressure group - multiplied. In 1961 an agreement about official fee rates was concluded between the mutual aid sector and associations of medical professionals, but was opposed by the 
League of Belgian Physicians. Another organisation, the Syndikale Kamers der Geneesheren, reacted by staging a doctors' strike against the provision of the 1963 law that encouraged fee regulation through the signing of conventions between mutual funds and physicians' organisations and provided penalties for doctors who did not respect the agreed fees. ${ }^{86}$ It took nearly twenty years to bring about stabilisation in the financing mechanism of the new public healthcare insurance system.

The post-1944 transformations had consequences for mutual societies as well. Competition between them changed in nature. Since all the wage earners were now insured and entitled to equal benefits, ${ }^{87}$ expansion was only possible at the expense of a competitor. As a result, mutual organisations redirected their competitive energy to the so-called free insurance market (i.e. the selling of additional health coverages not included in the compulsory social security package, such as the reimbursement of funeral costs or home nursing). Often, they shaped their 'free' offer to attract a particular profile of wage earners. Some Catholic insurance funds, for instance, organised pilgrimages to attract the most pious among the Belgian workers. Up to 1964, free insurances were also key to the health coverage of the self-employed, farmers and civil servants, whose medical expenses were not covered by social security. Because it lined up with Catholic ideas of subsidiarity, precaution and solidarity, Catholic mutual aid organisations prioritised the development of that particular market and soon became the biggest player in this field. During the Trente Glorieuses, the breadth of health coverage expanded in all sense of the term: the number of insured individuals grew, just as did the variety of risks covered.

The economic crisis of the 1970s put a halt to further expansion of the post-war system. In the following decade, major budget cuts in state support increased the share of healthcare costs payable by users, driving up the prices of medical services and stirring up calls for privatisation. In that impoverished context, the situation of healthcare workers degraded. In 1988, a law proposal from Flemish minister Jan Lenssens triggered an unprecedented wave of protest throughout the whole healthcare sector. Nurses, social and hospital workers, youth and disability care workers took to the streets, mostly of Flanders, in a movement of 'White Fury' ('Witte Woede, as it was referred to at the time) to denounce low and 


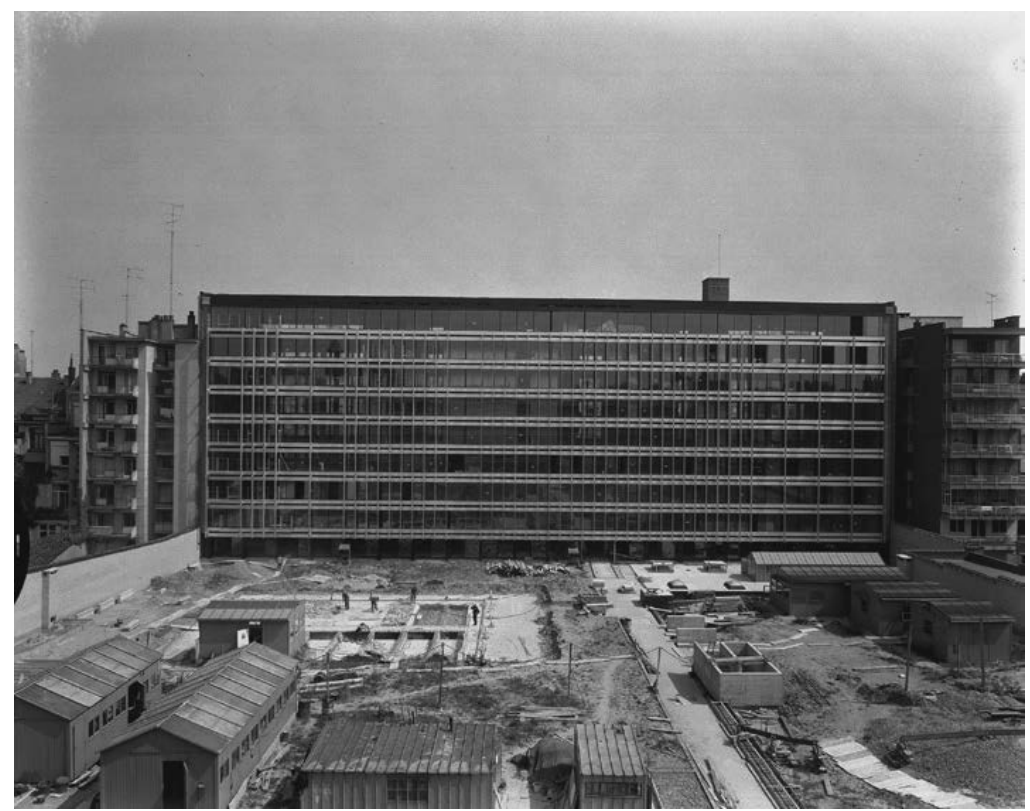

Figure 6.4 Construction of a new building for the INAMI inaugurated in 1974, when the economic crisis of the 1970s started.

unpaid salaries, high work pressure due to short-staffing and a general lack of recognition for their work (Figure 6.4). ${ }^{88}$

In the same period, private insurance companies that had entered the market of complementary insurances in the late 1960s established themselves as serious competitors for mutual funds. They offered hospital insurance (an insurance that was progressively coming to be seen as a necessary component of any salaryrelated benefit package) or insurance for those who sought the security of an additional sickness allowance in case of ill health. Mutual societies reacted by turning the non-compulsory hospital coverage into a complementary insurance product themselves, taking it out of their basic coverage and thus pushing it outside of the solidarity mechanism binding together their membership. On the other hand, the growing share of patient financial participation in healthcare costs, the reduction in social security reimbursements and the freedom physicians still enjoyed in some 
areas in the fixation of their own fees, created conditions in which the healthcare market could resume an easier expansion. In the late 1980s, the mutual aid sector broke into the market of international health coverage, which had been dominated up to then by private companies. ${ }^{89}$

In the past decades, the system has become more selective. Even though special supplementary benefits are directed at lower-income groups, ${ }^{90}$ individuals and families with insufficient means of subsistence have found themselves pushed progressively to the margins of healthcare. Despite efforts from the mutual aid sector to develop an offer aimed at the poorest, remedying the gaps in medical care has fallen more and more to non-governmental organisations (NGOs) such as Médecins du Monde/Dokters van de Wereld (Doctors of the World), a non-profit organisation that provides direct medical support to drug addicts, the homeless, undocumented and other people who have fallen off the healthcare radar. ${ }^{91}$ In other areas of public health today, NGOs will focus on specific diseases, like cancer for instance; by means of large-scale public campaigns, often with support from the media, they raise money to finance research and provide financial support to cancer patients. ${ }^{92}$

\section{Hospitals increasingly under state control after 1944}

The compulsory health insurance scheme had an immediate effect on public hospital finances. In the years following the 1925 reform of public assistance and the opening of public health facilities to paying patients, the patient population of the St-Elisabeth Hospital in Antwerp, for instance, was still made up of 60 to 80 per cent of indigent patients whose treatment had to be supported by municipalities. In 1945, that figure dropped to 10 per cent and stayed between 8 and 12 per cent the following years. ${ }^{93}$ This meant that roughly 90 per cent of the St-Elisabeth Hospital users now belonged to the 'paying patient category'; they could pay for their treatment themselves or, more likely, had insurance. The new compulsory system of health insurance generated a financial windfall, flowing directly from the state and the mutual aid sector to public hospital accounts. Hospitals were not used to receiving such large amounts of capital for the services they provided. In Brussels and in Antwerp, 
the local CAPs split the sums that they received from the INAMI in two, one half going to their hospitals, the other half to the salaries of public assistance physicians. A pool system was set up to redistribute the latter half between the CAPs' various departments; part of it was also reserved for medical equipment. However, this development did not solve the depth of the global public assistance deficit: in 1948, the shortfall of the ordinary accounts of all the CAPs was still estimated at 1 billion BF. As a result, the state created a new 'Fonds communal d'Assistance publique' (Vermeylen Law of 24 December 1948) $)^{94}$ - later referred to as the 'Fonds spécial d'Assistance publique' (law of 27 June 1956) - to help municipal CAPs reduce their debts. By 1962 the cumulated yearly deficit of the CAP hospitals was cut down to 755 million . $^{95}$

The salaries of public assistance - and, in particular, hospital physicians were another point of contention in the financing mechanism of the new healthcare system. In the first half of the twentieth century, hospital work was still considered charity work and the function of 'hospital doctor' was attractive mostly for the research possibilities it offered, the prestige it afforded and as a springboard for a career in private medicine. Hospital physicians were granted a temporary mandate, earned nothing more than a small symbolic compensation for their services and had to rely financially on their private practice to earn their living. That is the reason why most doctors in this period would only spend two hours a day at the hospital, generally in the morning, and few hospital medical activities took place in the afternoon. ${ }^{96}$ After the Second World War, the system of temporary mandates with limited compensation no longer seemed acceptable. Doctors aspired to become full-time employees and to fully take part in the daily life of their hospital. It took twenty years for this goal to be achieved, as is exemplified by the cases of Brussels (1967) and Antwerp (1971), both resulting in the creation of a professional union of hospital physicians. In Brussels the reorganisation of public assistance physician contracts and salaries was influenced by the new Centres Hospitaliers Universitaires (CHU) (university hospital centres) reform in France (1960), which pushed for financial support from universities and sought to define a better balance between on-site curing, teaching and research activities. ${ }^{97}$ In the aftermath of the physician strike of 1964 and a successful compromise on state-regulated medical fees, a national Joint Commission was 
tasked in 1967 to create a statute for hospital physicians but failed to reach a definitive solution. Minister Jean-Luc Dehaene settled the issue twenty years later, in $1986 .{ }^{98}$ In the meantime, the total number of physicians in all branches of medical services multiplied by three, going from 8,000 in 1950 to 24,000 in $1980 .{ }^{99}$

With the introduction of social security, the hospital sector became subject to more state regulation. Hospital accreditation appeared in 1945, funding the (re)construction of hospitals in 1950 (public) and 1953 (private). ${ }^{100}$ The Custer's law on hospitals of 1963 was the final step in the reorganisation of the Belgian health insurance system. Its purpose was, among others, to keep hospital admission free of charge for those who met the conditions of the compulsory health insurance policy. It was also to subsidise hospitals by contributing to the payment of daily hospitalisation fees (now calculated on a national basis), and to help abate the budget gaps burdening local CAPs and the municipalities that they were tied to. In that same movement, hospitals all came under state supervision. ${ }^{101}$ To be part of the system, each institution had to apply for accreditation, keep up with quality requirements, as well as adopt nationally standardised bookkeeping methods that would allow a comparison of hospital rates and statistics for the whole country. The standardisation of hospital administrative practices such as accounting was both a consequence of, and a condition to, the implementation of a national public healthcare system. In Belgium, the art and science of hospital management emerged as an issue before the Second World War and became a specialised field around the major post-war healthcare reforms. In the academic institutes of the St Raphael Hospital in Leuven, for instance, professionalisation began in 1940 and led to the creation of the first Centre for Hospital Sciences of the country in 1961. ${ }^{102}$

In the 1970s, the Ministry of Public Health was also compelled to reduce hospital funding, and initiated programmes supporting merger operations or aiming at reducing the number of hospital beds in Belgium. In 1976, the CAPs in charge of welfare and public healthcare in each municipality were renamed Centre Public d'Aide Sociale (CPAS) or Openbaar Centrum voor Maatschappelijk Welzijn (OCMW), but this did nothing to improve the indebted situation of public healthcare institutions. To allow more flexible governance practices and alternative financing sources and 
methods, hospital administrations were offered the possibility of a transfer into new administrative structures. In Brussels, all CPAS hospitals were integrated into the new Interhospitalière Régionale des Infrastructures de Soins (IRIS) hospital network in 1996. Antwerp followed in 2004, gathering its public hospitals together into its own Ziekenhuis Netwerk Antwerpen (ZNA) network. ${ }^{103}$ After years of debating the issue, CPAS themselves are now gradually being incited (Wallonia) or forced (Flanders) to merge with their municipalities. Tendencies towards cost control are hardening after the sixth state reform and the announcement of a necessary cut of 1 billion euros in healthcare expenditures. Among the actions taken recently is the grouping of all existing Belgian hospitals within a maximum of 25 different 'local-regional networks', each with their own legal personality and management body. One of the many objectives of this ongoing reform is to foster more effective coordination and collaboration between facilities, and allow the elimination of duplicate departments within the same network.

To replace the old subsidy system based on hospital daily rates, the law of 7 August 1987 created a new administrative body the Budget of Financial Means or Budget des Moyens Financiers (BMF) - tasked with determining the subsidy amount to be allocated yearly to each accredited hospital. The new calculations were based on each facility's number of 'certified' beds and on the total number of hospitalisation days recorded each year. That calculation scheme changed again with the law of 14 January 2002. Concurrently, a complex new system of financing was implemented: state subsidies would no longer be drawn from the budget of the Health Ministry, but instead would come from 'alternative financing', in this case VAT revenues (2004). ${ }^{104}$ In 2018, the main sources of hospital income can be summarised as follows: BMF subsidies from the health ministry (40 per cent), INAMI funding for healthcare and medical drugs (60 per cent). ${ }^{105}$

\section{Concluding remarks}

The sources for financing individual care multiplied as industrialisation made its way and social protection became a political issue. In the early nineteenth century, public authorities, charity 
and personal financial means financed care. Mutual societies were a means to pool small savings for investment in health, initially on a professional and segmented basis. The development of mutual societies and the financial support of public authorities included more and more people in the healthcare system. It was only after 1944 that employers had to contribute in a structural way to finance the health insurance of the wage earners. Even if since the late nineteenth century, it was argued that healthcare was a matter of national solidarity, it took some time for this idea to make its way. The two world wars were factors of acceleration in this process: after the First World War, the national state intervened more systematically in healthcare, while with the Second World War came the idea of social security.

Medical care can be thought of as a product to be consumed in the marketplace. This is the dominant point of view adopted by most researchers working on the history of social protection today. According to that perspective, social protection is a service offered by a series of market actors (mutual societies of various kinds, commercial insurance companies, etc.). ${ }^{106}$ In Belgium, the mutual aid sector, working within the three political pillars (Catholic, socialist and liberal) that structure Belgian social life, became the biggest provider of health coverage, for wage earners in particular. This dominant position is partly due to the system of subsidised liberty and the ever-increasing financial support of the state throughout the twentieth century. The implementation of the Belgian social security system after the Second World War changed very little in that regard because mutual aid funds retained their position as intermediary between the new public healthcare financing scheme and consumers.

Moreover, the fact that all the wage earners and not only those with a modest salary as in the Netherlands were covered limited the market for private companies. Those who were integrated later in the social security system such as the self-employed and civil servants could be served by the so-called free insurances offered by the mutual societies. This might explain the limited role of commercial insurances, as compared for instance to the Netherlands. ${ }^{107}$ The situation changed when after the crisis of the 1970s the coverage of the financial cost of care via the public system diminished: there was a market for additional insurances, covering hospital care. This 
market is a secondary market, not replacing basic care, and mutual societies are active on this market as well.

The provision of medical care in Belgium today is carried out by a mixture of public institutions and private non-profit initiatives springing from the mutual aid and Catholic sectors. This is the result of a long historical evolution. In the nineteenth century, local public relief institutions organised according to principles dating back from the French Revolution constituted the core of healthcare infrastructures. To counter the development of public intervention in the healthcare sector, Belgian Catholics expanded their own network of medical institutions. At that time, the central state had very little involvement in the provision of medical care. From the end of the nineteenth century on, it used the system of 'subsidised liberty' as a policy instrument and favoured private initiatives from mutual aid societies and Catholic organisations. Although state involvement grew significantly after the First World War, this tendency toward supporting and leaning on private initiatives was never fully reversed. As a result, Catholic institutions obtained a dominant position in the national field of healthcare.

Though it is very difficult to encompass the cost of care, nowadays it is assumed that both health and social care represent some 10 per cent of the GDP. ${ }^{108}$ The 'unbearable' burden of this cost is constantly being stressed in the media, which justifies the cuts in state subsidies. ${ }^{109}$ For half a century, the state has been struggling with the challenging equation between maintaining the solidarity principle of the post-Second World War social security and applying business logic to all aspects of society, especially healthcare. ${ }^{110}$ Is it possible to monetise the body?

\section{Notes}

1 https://ec.europa.eu/eurostat/statistics-explained/index.php?title= File:Healthcare_expenditure_by_financing_scheme,_2015_(\%25_ of_current_healthcare_expenditure)_FP18a.png (accessed 27 May 2021).

2 Martin Gorsky and Sally Sheard (eds), Financing Medicine: The British Experience since 1750, Routledge Studies in the Social History of Medicine, 24 (London: Routledge, 2006); H. F. van der Velden, Financiële toegankelijkheid tot de gezondheidszorg in Nederland. 
1850-1941. Medische armenzorg, ziekenfondsen en verenigingen voor ziekenhuisverpleging op nationaal en lokaal niveau (Schiedam, Roordaziekenhuis en Amsterdam) (Amsterdam: Amsterdam Unviersity Press, 1993); Un siècle de protection sociale en Europe. Colloque tenu au Sénat octobre 1996 (Paris: Association pour l'étude de l'histoire de la sécurité sociale, 2001).

3 Catharina Lis and Guy Vanthemsche, 'Sociale zekerheid in historisch perspectief', in De sociale zekerheid verzekerd? Referaten van het $22^{\text {ste }}$ Vlaams Wetenschappelijk Congres, ed. Marc Despontin and Marc Jegers (Brussels: VUB Press, 1995), 23-79, at 64; Robert Vonk, Recht of schade, 1900-2006. Een geschiedenis van particuliere ziektekostenverzekeraars en hun positie in het Nederlandse zorgverzekeringbestel (Amsterdam: Amsterdam University Press, 2013).

4 A good introduction and overview is Jan De Maeyer, Lieve Dhaene, Gilbert Hertecant and Karel Velle (eds), Er is leven voor de dood: tweehonderd jaar gezondheidszorg in Vlaanderen (Kapellen: Pelckmans, 1998).

5 Claude Bruneel, 'L'aurore de la médicalisation dans les Pays-Bas autrichiens', Annales de la Société belge d'histoire des hôpitaux, 28 (1993), 3-33.

6 See, for example, Sandra Bos, 'A tradition of giving and receiving: mutual aid within the guild system', in Craft Guilds in the Early Modern Low Countries: Work, Power, and Representation, ed. Maarten Prak (London/New York: Routledge, 2006), 174-93.

7 Pierre-Jean Niebes, Les frères cellites ou alexiens en Belgique. Monasticon (Brussels: Archives générales du Royaume, 2002).

8 Detailed information for the Antwerp hospital in several chapters in Jacques De Haes et al. (ed.), 750 jaar gasthuis op 't Elzenveld 12381988 (Brussels: Gemeentekrediet, 1988).

9 An overview of local interventions is in several chapters of L'initiative publique des communes en Belgique. Fondements historiques (Ancien Régime). 11e colloque international Spa 1982, Collection Histoire, série in- $8^{\circ}, \mathrm{n}^{\circ} 65$ (Brussels: Crédit Communal, 1984).

10 Claude Bruneel, 'L'aurore de la médicalisation'; Claude Bruneel, 'Ziekte en sociale geneeskunde: de erfenis van de verlichting', in De Maeyer et al., Er is leven voor de dood, 18-19, 25-6.

11 In the text: 'Les secours publics sont une dette sacrée. La société doit la subsistance aux citoyens malheureux'.

12 See, for instance, Dora Weiner, The Citizen-Patient in Revolutionary and Imperial Paris (Baltimore, MD: Johns Hopkins University Press, 1993), 6-14. 
13 Jean Imbert, 'La centralisation administrative des hôpitaux et de la bienfaisance dans les communes du département de la Dyle', Revue d'histoire du droit, 19 (1951), 58-104, 296-335; Jean Imbert, 'L'influence de la législation hospitalière dans les département belges et luxembourgeois (1795-1814)', Annales Universitatis Saraviensis, 2:4 (1953), 286-99. In 1856, on 2,531 municipalities, 2,514 had a welfare bureau, and 174 a civil hospitals commission. See P. Lentz, Des institutions de bienfaisance et de prévoyance en Belgique. 1850 à 1860. Résumé statistique (Brussels: Ministère de la Justice, 1866), 4 [Extrait de l'exposé de la situation du Royaume].

14 Claire Dickstein-Bernard, 'L'histoire des hôpitaux bruxellois au XIX' siècle: un domaine encore inexploré', Annales de la Société belge d'histoire des hôpitaux, 15 (1977), 68.

15 Ibid., 69-70. For the finances of the hospices of Louvain, see G.-J. Servranckx, Mémoire historique et statistique sur les Hospices civils et autres établissements de bienfaisance de la ville de Louvain (Louvain, 1843; reprint AGR no. 2, Brussels, 1995), 45-53.

16 Karel Velle, 'De overheid en de zorg voor de volksgezondheid', in De Maeyer et al., Er is leven voor de dood, 130-50, at 139; Karel Velle, 'De belangenverdediging van de geneesheren', in De Maeyer et al., Er is leven voor de dood, 167-78, at 177; Paule Verbruggen, 'De volkskliniek: een socialistische polikliniek in Gent', in De Maeyer et al., Er is leven voor de dood, 233-41, at 233; Geert Souvereyns, Solidair in gezondheid. 100 jaar christelijk mutualisme in de Kempen (Leuven: CM/KADOC, 2001), 22; Karel Velle, De nieuwe biechtvaders. De sociale geschiedenis van de arts in België (Leuven: Kritak, 1991), 98.

17 Marie-Sylvie Dupont-Bouchat, 'Entre charité privée et bienfaisance publique: la philanthropie en Belgique au XIXe siècle', in Philanthropies et politiques sociales en Europe (XVIIIe-XXe siècles). Association de recherche sur les philanthropies et les politiques sociales. Actes du colloque Paris 1992, ed. Colette Bec, Catherine Duprat, Jean-Noël Luc and Jacques-Guy Petit (Paris: Anthropos, 1994), 29-44, at 40.

18 Jacques Lory and Jean Luc Soete, 'Implantation et affirmation (18451914)', in Jan De Maeyer and Paul Wynants (eds), De Vincentianen in België. Les Vincentiens en Belgique 1842-1992, Kadoc Studies 14 (Leuven: Universitaire Pers, 1992), 45-80, at 69; Rudolf Rezsohazy, Histoire du mouvement mutualiste chrétien en Belgique (Paris: Erasme, 1957), 57; Souvereyns, Solidair in gezondheid, 22-3; Wilfried Wouters, 'De bewogen start van het Sint Vincentius a Paolo genootschap in België (1841-1848)', in De Maeyer and Wynants, De Vincentianen in België, 27-43. 
19 Lis and Vanthemsche, 'Sociale zekerheid in historisch perspectief', 47, 52-3; Patricia Quaghebuer, Welzijn door vooruitzicht. Een kijk op de christelijke mutualiteitsbeweging in het arrondissement Gent tijdens de $19^{\text {de en }} 20^{\text {ste }}$ eeuw (Ghent: Verbond der Christelijke Mutualiteiten van het arrondissement Gent, 1986), 38.

20 Lentz, Des institutions de bienfaisance, 5-7. See also Chapter 2, pp. 68-9.

21 Jos De Belder, 'Het arbeiderssparen 1850-1890', in De Belgische spaarbanken. Geschiedenis, recht, economische funktie en instellingen (Tielt: Lannoo, 1986), 91-120.

22 Souvereyns, Solidair in gezondheid, 40; Dominque Boucher, 'Les catholiques et le mouvement mutualiste dans la province de Namur de 1886 à 1914', in Le Monde Catholique et la Question Sociale (18911920), ed. Françoise Rosart and Guy Zelis (Brussels: EVO, 1992), 89-112, at 92.

23 Karel Veraghtert and Brigitte Widdershoven, Twee eeuwen solidariteit. De Nederlandse, Belgische en Duitse ziekenfondsen tijdens de negentiende en twintigste eeuw (Amsterdam: Aksant/HiZ, 2002), 42.

24 Velle, De nieuwe biechtvaders, 98.

25 Rezsohazy, Histoire du mouvement mutualiste chrétien, 74; Jolien Gybels, 'Reassessing the pauper burial: the disposal of corpses in nineteenth-century Brussels', Mortality, 23 (2018), 184-98; Tinne Claes, "By what right is the scalpel put in the pauper's corpse?" Dissections and consent in late nineteenth-century Belgium', Social History of Medicine, 31 (2018), 258-77.

26 Paule Verbruggen, 'The mutualist movement in Belgium', in Social Security Mutualism. The Comparative History of Mutual Societies, ed. Marcel van der Linden (Bern: Peter Lang, 1996), 419-20; Boucher, 'Les catholiques', 91; Souvereyns, Solidair in gezondheid, 32.

27 Veraghtert and Widdershoven, Twee eeuwen solidariteit, 44.

28 Griet van Meulder, 'Mutualiteiten en ziekteverzekering in België, 1886-1914', Belgisch Tijdschrift voor Nieuwste Geschiedenis, 27 (1997), 83-134, at 86; Veraghtert and Widdershoven, Twee eeuwen solidariteit, 44.

29 Boucher, 'Les catholiques', 92; Verbruggen, 'The mutualist movement, 421; Rezsohazy, Histoire du mouvement mutualiste chrétien, 61.

30 Van Meulder, 'Mutualiteiten', 86; E. Gerard, 'De christelijke mutualiteiten', in De christelijke arbeidersbeweging in België 18911991, ed. E. Gerard, Kadoc Studies 11 (Leuven: Universitaire Pers, 1991), vol. 2, 66-145, at 73; Rezsohazy, Histoire du mouvement mutualiste chrétien, 337, 361. 
31 Jan De Maeyer and Lieve Dhaene, 'Sociale emancipatie en democratisering: de gezondheidszorg verzuild', in De Maeyer et al., Er is leven voor de dood, 151-66, at 152; Van Meulder, 'Mutualiteiten', 94-7, 103.

32 Jo Deferme, Uit de ketens van de vrijheid. Het debat over de sociale politiek in België, 1886-1914, KADOC-Studies 32 (Leuven: Universitaire Pers, 2007), 337, 414.

33 Van Meulder, 'Mutualiteiten', 103-5.

34 As can been witnessed through the evolution of pharmaceutics and medical services advertising. See Velle, De nieuwe biechtvaders, 99.

35 Boucher, 'Les catholiques', 95.

36 Verbruggen, 'The mutualist movement', 424-5; De Maeyer and Dhaene, 'Sociale emancipatie', 156; Verbruggen, 'De Volkskliniek', 235; Souvereyns, Solidair in gezondheid, 119; Deferme, Uit de ketens, 340; Rezsohazy, Histoire du mouvement mutualiste chrétien, 136.

37 Karel Velle, 'De belangenverdediging van de geneesheren', in De Maeyer et al., Er is leven voor de dood, 167-78, at 173.

38 Souvereyns, Solidair in gezondheid, 127.

39 Daniel Vanacker, Een averechtse liberaal. Leo Augusteyns en de liberale arbeidersbeweging (Ghent: Academia Press/Liberaal Archief, 2008), 365-78.

40 Rezsohazy, Histoire du mouvement mutualiste chrétien, 109.

41 Michel Vermote, Gezondheid. 75 Jaar Nationaal Verbond van socialistische mutualiteiten (Ghent: AMSAB, 1988), 22.

42 Quaghebeur, Welzijn door vooruitzicht, 61.

43 Souvereyns, Solidair in gezondheid, 68-72, 127-8; Rezsohazy, Histoire du mouvement mutualiste chrétien, 139.

44 Souvereyns, Solidair in gezondheid, 127.

45 Els Witte, Alain Meynen and Dirk Luyten, Histoire politique de la Belgique de 1830 à nos jours (Brussels: Edition Samsa, 2017), 11756; De Maeyer and Dhaene, 'Sociale emancipatie en democratisering', 151-66.

46 Verbruggen, 'De Volkskliniek', 236.

47 Souvereyns, Solidair in gezondheid, 119.

48 Boucher, 'Les Catholiques', 101.

49 Van Meulder, 'Mutualiteiten', 118; Griet van Meulder, 'Vrouwenmutualiteiten of familiemutualiteiten? De betekenis van het mutualisme voor vrouwen rond de eeuwwisseling (1885-1914)', Brood en Rozen, 3 (1997), 38-349, at 40.

50 Souvereyns, Solidair in gezondheid, 125; Van Meulder, 'Vrouwenmutualiteiten', 40.

51 De Maeyer and Dhaene, 'Sociale emancipatie', 156. 
52 Van Meulder, 'Mutualiteiten', 119-20.

53 Ibid., 112, 120-5.

54 Claudine Marissal, Protéger le jeune enfant: Enjeux sociaux, politiques et sexués (Belgique, 1890-1940), (Brussels: Editions de l'Université de Bruxelles, 2014), 109-28; Godelieve Masuy-Stroobant, 'Le choc de la guerre de 14-18: une avancée pour les oeuvres de l'enfance', in Mères et nourrissons: de la bienfaisance à la protection médico-sociale (1830-1945), ed. Godelieve Masuy-Stroobant and Perrine C. Humblet (Brussels: Labor, 2004), 159-75; Gerard, 'De christelijke mutualiteiten', 90; Vermote, Gezondheid, 35; De Maeyer and Dhaene, 'Sociale emancipatie', 156-8; Luc De Munck, Altijd troosten. Belgische verpleegsters tijdens de Eerste Wereldoorlog (Amsterdam: Amsterdam University Press, 2018).

55 The First Ministry of Health created in 1936 was short-lived. See Velle, 'De overheid', 136-8.

56 Verbruggen, 'De Volkskliniek', 236.

57 Ibid.; De Maeyer and Dhaene, 'Sociale emancipatie', 158-63.

58 Gerard, 'De Christelijke mutualiteiten', 100.

59 Velle, 'De overheid', 139; Piet Clement, Government Consumption and Investment in Belgium, 1830-1940: 1940: The Reconstruction of a Database (Leuven: Leuven University Press/Koninklijke Vlaamse Academie van België voor Wetenschappen en Kunsten, 2000), 114.

60 Ineke Meul, 'De professionalisering van het medisch-specialistisch beroep in het kader van de verplichte Ziekte-en invaliditeitsverzekering in België (1944-2014)' (PhD thesis, University of Antwerp, 2016), 89; Peter Scholliers, 'Loonontwikkeling, conjunctuur en arbeidsverhoudingen in het bouwvak in Brussel en Parijs, 1855-1940', Belgisch Tijdschrift voor Nieuwste Geschiedenis, 21 (1990), 1-47, at 42.

61 Souvereyns, Solidariteit in gezondheid, 167.

62 Lis and Vanthemsche, 'Sociale zekerheid in historisch perspectief', 68.

63 Verbruggen, 'The mutualist movement', 426.

64 Vermote, Gezondheid, 35.

65 Verbruggen, 'De Volkskliniek', 238.

66 De Maeyer and Dhaene, 'Sociale emancipatie', 156-8; E. Geerkens, 'Les mutualités professionnelles, un axe majeur de la politique sociale patronale pendant l'entre-deux-guerres en Belgique?', Revue Belge de Philologie et d'Histoire, 80 (2002), 1275-349.

67 Quaghebeur, Welzijn door vooruitzicht, 176.

68 Vermote, Gezondheid, 67.

69 Verbruggen, 'The mutualist movement', 425; Souvereyns, Solidair in gezondheid, 205. 
70 Claire Dickstein-Bernard, 'L'initiative communale en matière hospitalière entre 1795 et 1940, et plus particulièrement à Bruxelles et dans les faubourgs de la capitale', in L'initiative publique des communes en Belgique, 1795-1940, Actes du 12e colloque international, Spa 1984, Collection histoire, série in- $8^{\circ}, 71$ (Brussels: Crédit communal, 1986), 395-6, 400-4.

71 David Guilardian, 'Saint-Pierre et Bordet: De l'Art Deco au Modernisme', in Du monumental au fonctionnel: l'architecture des hôpitaux publics bruxellois (XIXe-XXe siècles), ed. Claire DicksteinBernard, David Guilardian, Astrid Lelarge and Judith Le Maire (Brussels: CIVA, 2005), 75-7.

72 'Hospitals which, yesterday still, were considered asylums for the poor, have become healthcare establishments offering all the required guarantees, frequented not only by the poor but by a large clientele made out for the most part of individuals who, thanks to social security, are now paying or semi-paying patients.' J. Glineur and P. Rochet, Guide pratique de l'administration des CAP (Brussels, 1955), 11 (see also p. 194); Dickstein-Bernard, 'L'initiative communale', 393-4.

73 Glineur and Rochet, Guide pratique, 194-5; Dickstein-Bernard, 'L'initiative communale', 393-4.

74 Jacques De Haes et al., 'De overlevingsstrijd van een ziekenhuis', in De Haes et al., 750 jaar gasthuis, 256-7.

75 Note that the number of patients was not calculated on the same basis throughout the period. De Haes et al., 'De overlevingsstrijd', 255.

76 Rapport Annuel de 1926 (Brussels: Assistance publique, [1927]), 24-5.

77 Ibid., 12 and 32-3.

78 Guilardian, 'Saint-Pierre et Bordet', 91, 94, 105, 109.

79 Dickstein-Bernard, 'L'initiative communale', 389.

80 Beds in military hospitals are not included in these figures. See Bernard Delvaux, 'Les hôpitaux en Belgique. Évolution de l'infrastructure et de la politique hospitalière', Courrier Hebdomadaire du CRISP, 1140-1 (1986), 6.

81 Karel Vanacker, Kroniek van een overleving: de Belgische ziekenfondsen tijdens de Tweede Wereldoorlog (Ghent: AMSAB, 2010); Gerard, 'De christelijke mutualiteiten', 103.

82 Guy Vanthemsche, De beginjaren van de sociale zekerheid in België, 1944-1963 (Brussels: VUB Press, 1994), 56-77.

83 Peter Heyrman, Joris Colla and Noortje Lambrichts, De sociale zekerheid van zelfstandigen in België 1937-2017. Solidariteit en verantwoordelijkheid (Herent: KADOC/Zenito, 2017), 147-8.

84 Vanthemsche, De beginjaren, 127. 
85 Meul, De professionalisering, 126.

86 Vanthemsche, De beginjaren, 127-157; Klaartje Schrijvers, 'De artsenstaking van 1964. Of hoe de artsen een machtig eenheidsfront wisten te vormen in hun strijd tegen de overheid', Bijdragen tot de Eigentijdse Geschiedenis, 16 (2005), 57-89; Guy Vanthemsche, 'Les mutualités et la protection sociale en Belgique (milieu du XIXe-fin du XXe siècle)', Histoire et Sociétés. Revue européenne d'histoire sociale, 16 (2005), 20-31; Meul, De professionalisering, 163-4.

87 Except for the young men and women entering the labour market but who often remained loyal to their parents and family's insurance fund anyway.

88 For the 'Witte Woede' movement, see Erik Henderickx et al., Ze vragen zoveel mijnheer. De kwalitatieve kant van de witte woede (Antwerpen: Ruca Rijksuniversitair Centrum, 1993); and Marianne De Troyer, 'Blouses blanches en colère. Quelles sont les résultantes des mouvements de grèves et des négociations des dernières années (1989-1992)?', L'année sociale (1992), 110-19.

89 Etienne Arcq and Pierre Blaise, 'Politieke geschiedenis van de sociale zekerheid in België', Belgisch Tijdschrift voor Sociale Zekerheid, 40 (1998), 491-746, at 673-6; Herman Deleeck, De architectuur van de welvaartsstaat opnieuw bekeken (Leuven: Acco, 2000), 421.

90 Bea Cantillon and Linde Buysse, De staat van de welvaartsstaat (Leuven: Acco, 2016), 51.

91 Arcq and Blaise, 'Politieke geschiedenis', 677.

92 www.komoptegenkanker.be (accessed 27 May 2021).

93 It would rise again after 1957 in this hospital, but not in Stuivenberg. See De Haes et al., 'De overlevingsstrijd', 257-60.

94 Anne Moureaux-van Neck, 'Assistance publique 1856-1956', Acta Historica Bruxellensia. Travaux de l'Institut d'Histoire de l'Université Libre de Bruxelles, 1 (1967), 62-71.

95 'Le problème hospitalier en Belgique', Courrier hebdomadaire $d u$ CRISP, 395 (1968), 6.

96 De Haes et al., 'De overlevingsstrijd', 286; Marcel Franckson, 'Plan Badon', in Du côté de Brugmann. Un hôpital dans son siècle, ed. Daniel Désir (Brussels: Éditions Ercée, 2006), 83-4.

97 Madeleine Moulin, La genèse de l'hôpital Erasme. Un essai de sociologie compréhensive (Brussels: Editions de l'ULB, 1987), 94-6.

98 De Haes et al., 'De overlevingsstrijd', 281-2.

99 Samuel Halter, 'Les hôpitaux belges de 1830 à 1980', L'Hôpital Belge, 148 (1980), 20.

100 Arrêté du Régent 21 March 1945, art. 56; Arrêté du Régent 2 June 1949; Halter, 'Les hôpitaux belges de 1830 à 1980', 20. 
10130 jaar ziekenhuiswet in België (Brussels: Ministry of Health, 1993); 'Le problème hospitalier en Belgique'.

102 Joris Vandendriessche, 'Reforming on paper: Accounting practices in the Leuven academic hospitals, 1920-60', in Axel C. Hüntelmann and Oliver Falk (eds), Accounting for health: Calculation, paperwork and medicine, 1500-2000 (Manchester: Manchester University Press, 2021).

103 On the financial background in Brussels, see Centre public d'aide sociale de Bruxelles. 18 ans au service des Bruxellois. 1977-1995 (Brussels: CPAS, 1995), 110-15; '40 ans de chantiers hospitaliers bruxellois. Entretien avec Arnold Czerwonogora', in Christine Dupont ed., Hôpitaux bruxellois. De la charité à la santé publique, Cahiers de la Fonderie, 52 (Brussels: La Fonderie, 2017), 39-46.

104 See, for example, the report by the Cour des Comptes, Nouvelles règles de financement des hôpitaux, Brussels, February 2006, 8, 11-12.

105 See the latest statistics summarised by the Health Ministry in www. health.belgium.be/sites/default/files/uploads/fields/fpshealth_theme_ file/vue_densemble_donnees_generales_hopitaux_2019_3.pdf (accessed 7 June 2021).

106 Jacques van Gerwen and Marco van Leeuwen (eds), Studies over zekerheidsarrangementen. Risico's, risicobestrijding en verzekeringen in Nederland vanaf de Middeleeuwen (Amsterdam: Den Haag, 1998).

107 Vonk, Recht of schade?

108 Federal statistics, see the Introduction to this volume.

109 See also the problems with the increase of life expectancy and ageing population in Iris Loffeier, Benoît Majerus and Thibauld Moulaert (eds), Framing Age: Contested Knowledge in Science and Politics (London: Routledge, 2017).

110 For example, Jean Hermesse, 'Soins de santé: logique commerciale et/ ou solidariste?', La Lettre des Académies, 8 (2007), 4-5.

\section{Selected bibliography}

De Maeyer, Jan, Dhaene, Lieve, Hertecant Gilbert and Velle, Karel (eds), Er is leven voor de dood: tweehonderd jaar gezondheidszorg in Vlaanderen (Kapellen: Pelckmans, 1998).

Dickstein-Bernard, Claire, 'L'initiative communale en matière hospitalière entre 1795 et 1940, et plus particulièrement à Bruxelles et dans les faubourgs de la capitale', in L'initiative publique des communes en Belgique, 17951940, Actes du 12e colloque international, Spa 1984, Collection histoire, série in- $8^{\circ}$, vol. 71 (Brussels: Crédit Communal, 1986), 375-404. 
Lis, Catharina and Vanthemsche, Guy, 'Sociale zekerheid in historisch perspectief', in Marc Despontin and Marc Jegers (eds), De sociale zekerheid verzekerd? Referaten van het 22ste Vlaams Wetenschappelijk Economisch Congres (Brussels: VUB Press, 1995), 23-79.

Van Meulder, Griet, 'Mutualiteiten en ziekteverzekering in België, 18861914', Belgisch Tijdschrift voor Nieuwste Geschiedenis, 27 (1997), 83-134.

Vanthemsche, Guy, De beginjaren van de sociale zekerheid in België, 1944-1963 (Brussels: VUB Press, 1994) [in French: La sécurité sociale: les origines du système belge, le présent face à son passé, Politique et Histoire, 15 (Brussels: De Boeck, 1994)].

Velle, Karel, De nieuwe biechtvaders. De sociale geschiedenis van de arts in België (Leuven: Kritak, 1991).

Veraghtert, Karel and Widdershoven, Brigitte, Twee eemwen solidariteit. De Nederlandse, Belgische en Duitse ziekenfondsen tijdens de negentiende en twintigste eeuw (Amsterdam: Aksant/HiZ, 2002).

Verbruggen, Paule, 'The mutualist movement in Belgium', in Marcel van der Linden (ed.), Social Security Mutualism: The Comparative History of Mutual Societies (Bern: Peter Lang, 1996), 419-29. 